\title{
RANCANGAN APLIKASI KEPEGAWAIAN DAN PENGGAJIAN DI STO KALIABANG BEKASI UTARA BERBASIS DESKTOP
}

\author{
M. Agung Ifanah \\ Teknik Informatika, Fakultas Teknik dan Ilmu Komputer, Universitas Indraprasta PGRI Jakarta \\ Jalan Raya Tengah No 80, Kelurahan Gedong, Pasar Rebo, Jakarta Timur \\ agungifanah4@gmail.com
}

\begin{abstract}
ABSTRAK
STO Telkom Kaliabang Bekasi Utara adalah sebuah perusahaan di bawah naungan PT. Telkom yang khusus bergerak dibidang marketing. Sistem pengolahan data penggajian pegawai pada STO Telkom Kaliabang Bekasi Utara masih bersifat sederhana. Data pegawai tiap bulan masih dicatat dalam sebuah buku khusus, dan untuk menyerahkan bukti laporan gaji masih bersifat konvensional. Masalah yang timbul adalah ketidak konsistenan data yang dapat menyebabkan kerangkapan data, apabila dalam pencarian data membutuhkan waktu yang sangat lama. Tujuan merancang suatu aplikasi kepegawaian dan penggajian untuk memproses pengolahan data kepegawaian dan penggajain yang ada saat ini. Perangkat aplikasi yang telah dibuat dengan bahasa pemrograman Java NetBeans 8.0.2 dan penyimpanan data pada database MySQL dapat memberikan kelancaran dalam proses menginput dan penyimpanan data-data serta laporan-laporan yang diberikan kepada pimpinan perusahaan. Metode penelitian yang digunakan dengan metode Research and Development yang dapat mampu menyelesaikan permasalahan. Hasil dari penelitian ini menciptakan suatu aplikasi yang dapat memproses pengolahan data pegawai dan menghitung gaji pegawai pada STO Telkom Kaliabang Bekasi Utara secara terkomputerisasi sehingga menghasilkan laporan yang tersimpan dengan baik dan memberikan hasil secara cepat dan akurat.
\end{abstract}

Kata Kunci: Aplikasi, Kepegawaian, Penggajian Desktop

\begin{abstract}
STO Telkom Kaliabang Bekasi Utara is a company under the auspices of PT. Telkom which is specifically engaged in marketing. The employee payroll data processing system at STO Telkom Kaliabang North Bekasi is still simple. Employee data every month is still recorded in a special book, and submitting proof of salary reports is still conventional. The problem that arises is the inconsistency of data which can cause duplicate data, if the data search takes a very long time. The purpose of designing a staffing and payroll application to process the current staffing and payroll data processing. Application tools that have been created using the Java NetBeans 8.0.2 programming language and data storage in the MySQL database can provide smooth processing of input and storage of data and reports provided to company leaders. The research method used is the Research and Development method that can solve problems. The results of this study create an application that can process employee data processing and calculate employee salaries at STO Telkom Kaliabang Bekasi Utara computerized so as to produce reports that are stored properly and provide results quickly and accurately.
\end{abstract}

Key Word: Application, Employee Affair, Payroll, Desktop

\section{PENDAHULUAN}

Pada zaman era globalisasi ini informasi sangatlah penting bagi sebuah perusahaan (Tani, Bagre, \& Adam, 2018). Informasi dari satu bagian saling terkait dengan bagian lainya, sehingga informasi yang diberikan oleh suatu bagian sangat mempengaruhi aktivitas bagian yang lainya (Suhaimi, Sriasih, \& Nurkholis, 2018). Informasi yang cepat tepat dan terintegrasi akan memperlancar proses pada bagian yang terkait yang ada dalam suatu perusahaan. Penggajian dianggap sebagai struktur yang sangat berperan penting dalam berbagai sektor menggunakan data yang sesuai di tempat mereka berkontribusi. Sedangkan sistem penggajian mempermudah proses pemberian gaji kepada pegawai (Dede Firmansyah, 2020).

Saat ini banyak aplikasi yang dibuat untuk mempermudah perhitungan gaji pegawai. Dalam aplikasi gaji memudahkan dalam proses menyimpan dan mencari data yang dibutuhkan. Aplikasi gaji mengurangi kerumitan dengan tumpukan kertas, banyaknya arsip yang banyak 
memakan tempat dan membutuhkan waktu yang cukup lama untuk mencarinya. Pemanfaatan aplikasi gaji akan membuat proses penggajian menjadi benar dan maksimal juga mengoptimalkan kinerja bagian keuangan (Widyasari, 2015).

STO Telkom Kaliabang Bekasi Utara adalah sebuah perusahaan di bawah naungan PT. Telkom yang khusus bergerak dibidang marketing. Sistem pengolahan data penggajian pegawai pada STO Telkom Kaliabang Bekasi Utara masih bersifat sederhana. Data pegawai tiap bulan masih dicatat dalam sebuah buku khusus, dan untuk menyerahkan bukti laporan gaji masih bersifat konvensional. Masalah yang timbul adalah ketidak konsistenan data yang dapat menyebabkan kerangkapan data, apabila dalam pencarian data membutuhkan waktu yang sangat lama karena masih menggunakan sistem yang konvensional,dan keamanan data pun masih kurang terjamin (Azizah, 2017).

Dengan permasalahan tersebut, perlu ada nya suatu sistem yang terkomputerisasi dalam penyelesaiannya. Sistem adalah sekelompok unsur yang erat hubungannya satu dengan yang lain, yang berfungsi bersama-sama untuk mencapai tujuan (Sutabri, 2012). Sistem merupakan suatu kumpulan dari komponenkomponen yang membentuk satu kesatuan (Tyoso, 2016). Pembangunan sistem adalah sekumpulan aktivitas yang menggambarkan secara rinci bagaimana sistem akan berjalan. Hal itu bertujuan untuk menghasilkan produk perangkat lunak yang sesuai dengan kebutuhan user (Satzinger, J. W., Jackson, R. B., Burd, n.d.).

Dengan adanya komputer diharapkan dapat membantu dalam pelayanan yang akan diberikan kepada pasien dengan begitu pelayanan yang diberikan dapat semaksimal mungkin (Fatkhudin \& Alifiani, 2017). Tujuan utama dari adanya Klinik Cireundeu Medika adalah menyediakan layanan kesehatan yang bermutu namun dengan biaya yang relatif terjangkau untuk masyarakat, terutama masyarakat dengan kelas ekonomi menengah ke bawah (Rahmat Tullah, 2019).

Diharapkan dengan adanya suatu sistem informasi dapat menangani permasalahan yang ada di perusahaan tersebut. Sistem adalah setiap sesuatu terdiri dari obyek-obyek, atau unsur-unsur, atau komponen-komponen yang bertata kaitan dan bertata hubungan satu sama lain, sedemikian rupa sehingga unsur-unsur tersebut merupakan satu kesatuan pemrosesan atau pengolahan yang tertentu. (Prasojo, 2011)

Perancangan sistem informasi pengolahan data pegawai dan penggajian secara terkomputerisasi sehingga menghasilkan laporan yang tersimpan dengan baik dan memberikan hasil secara cepat dan akurat. Aplikasi yang dapat membantu dan mempercepat kinerja bagian keuangan dalam membuat laporan penggajian perbulan.

\section{METODE PENELITIAN}

Peneliti menggunakan metode Research and Development dalam penyelesaian penelitian ini. (Sugiyono, 2016) Dalam pelaksanaan R\&D, ada beberapa metode yang digunakan yaitu metode deskriptif, evaluatif dan eksperimental. Metode penelitian deskriptif digunakan dalam penelitian awal untuk menghimpun data tentang kondisi yang ada yaitu penulis membutuhkan data-data yang dapat menunjang tercipta nya suatu sistem informasi pengolahan data pegawai dan penggajian seperti data pegawai, data jabatan, data presensi, data penggajian dan data bonus pegawai terdahulu yang masih tersimpan secara manual didalam buku besar. Metode evaluatif digunakan untuk mengevaluasi proses ujicoba pengembangan suatu produk, dalam proses ini penulis melakukan ujicoba terhadap suatu sistem yang telah dirancang agar tidak ada terjadi kesalahan dalam proses penginputan data serta pelaporan bulanan kepada pimpinan. Dan metode eksperimen digunakan untuk menguji keampuhan dari produk yang dihasilkan, dalam proses yang terakhir ini perlu dilakukan pengujian akhir yang diharapkan bahwa sistem yang dirancang oleh penulis dapat berjalan dengan baik dan sesuai dengan kebutuhan dna terfokus pada proses pengolahan data pegawai dan penggajian pada STO Telkom Kaliabang Bekasi Utara.

\section{HASIL DAN PEMBAHASAN Alternatif Penyelesaian Masalah}

Untuk mencari solusi dalam permasalahan yang ada maka penulis membuat suatu sistem yang akan membantu dalam menyelesaikan masalah 
tersebut. Berdasarkan analisis sistem yang sedang berjalan saat ini penulis melihat beberapa kelemahan dan pokok permasalahan yang terdapat pada sistem pengolahan data kepegawaian dan penggajian di atas, maka penulis memberikan saran beberapa alternatif penyelesaian masalah diantaranya:

1. Merancang sistem informasi terkomputerisasi yang dapat membantu dalam proses penginputan data pegawai, data jabatan, data presensi, perhitungan gaji dan bonus pegawai di STO Kaliabang Bekasi Utara.

2. Perancangan database untuk sistem sehingga penyimpanan data tidak menggunakan media kertas lagi.

3. Data yang ada disimpan ke hardisk dan membuat backup-an data.

4. Membuat sistem informasi kepegawaian dan penggajian yang mudah dipahami oleh bagian administrasi dan bagian keuangan agar mudah digunakan.

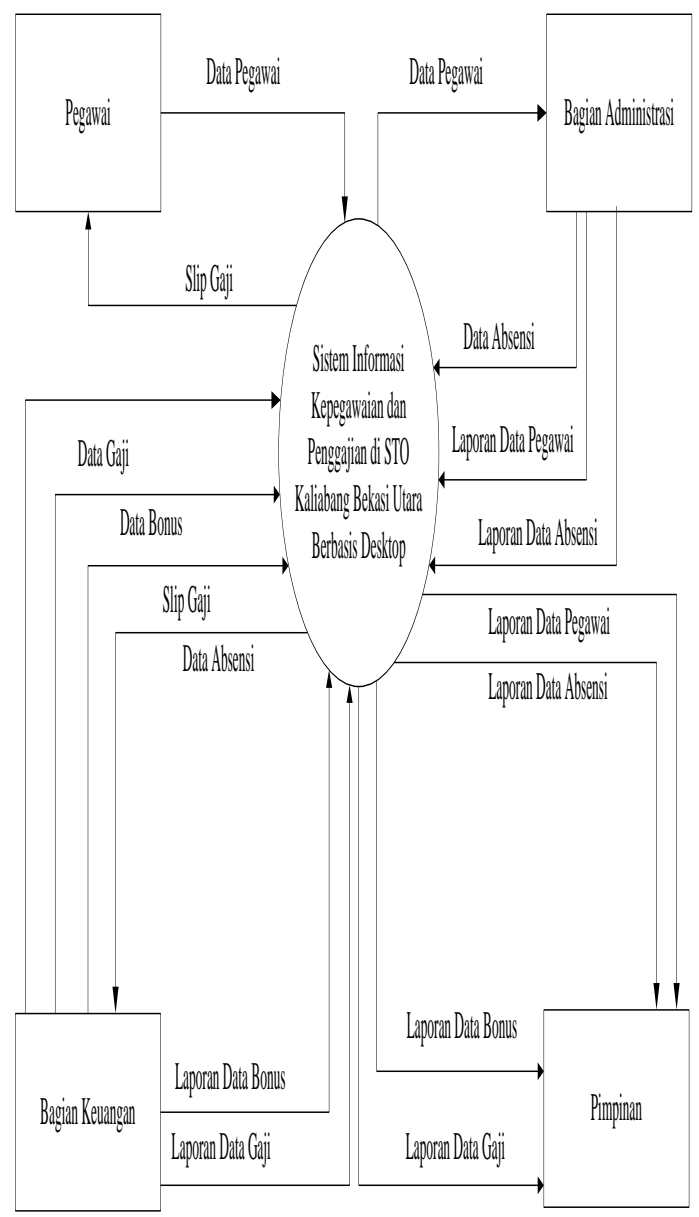

Gambar 1. Diagram Konteks

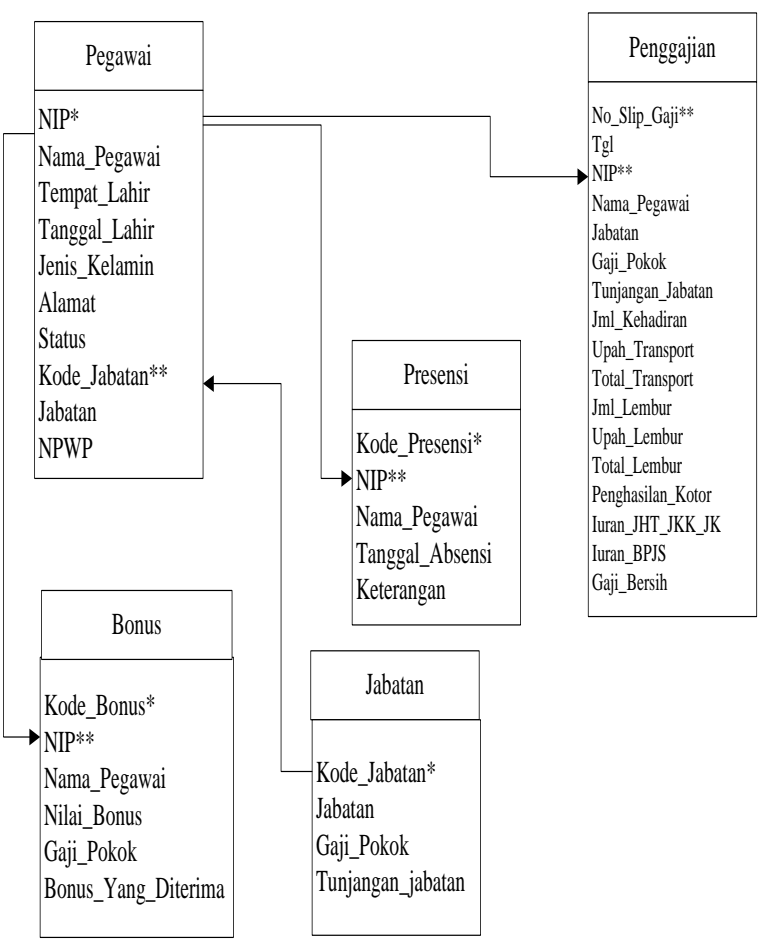

Gambar 2. Normalisasi

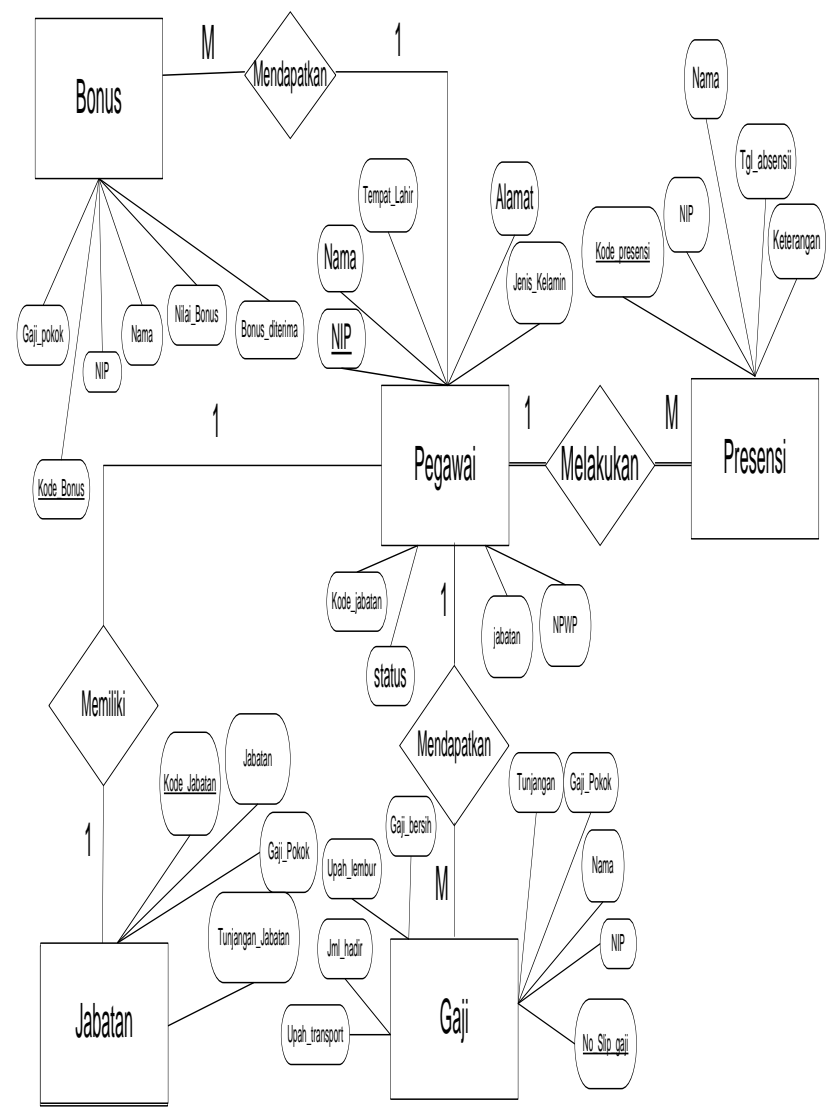

Gambar 3. ERD (Entity Relationship Diagram)

654 | Rancangan Aplikasi Kepegawaian dan Penggajian di STO Kaliabang Bekasi Utara Berbasis Desktop 
Berikut adalah tampilan layar dan hasil pengujian pada software program yang telah di buat dengan bahasa pemrograman Java.

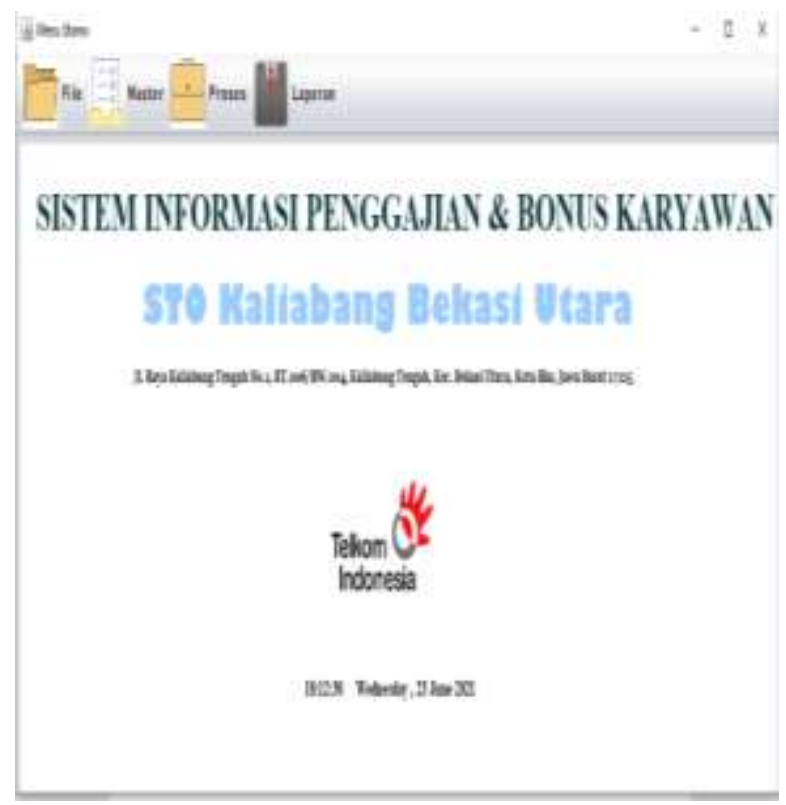

Gambar 4. Form Menu Utama

Layar di atas menampilkan tampilan Menu Utama pada Sistem Informasi Penggajian dan Bonus Karyawan STO Kaliabang Bekasi Utara. Pada layar utama tersedia menu bar yang terdiri dari master data yang digunakan untuk memasukkan data yang berkaitan dengan data pegawai, data jabatan, data presensi, data penggajian, data bonus dan laporan-laporan serta slip gaji karyawan.

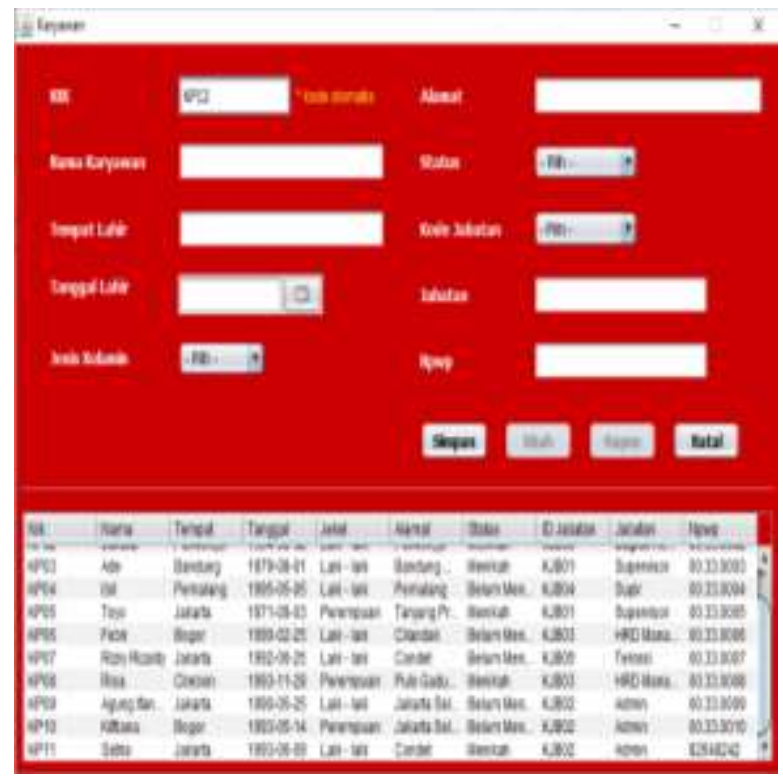

Gambar 5. Form Data Pegawai
Layar di atas menampilkan tampilan form data pegawai. Pada layar form data pegawai untuk meng-input data pegawai yang terdiri dari NIP, Nama Pegawai, Tempat Lahir, Tgl Lahir, Jenis Kelamin, Alamat, Status, Kode Jabatan, NPWP.

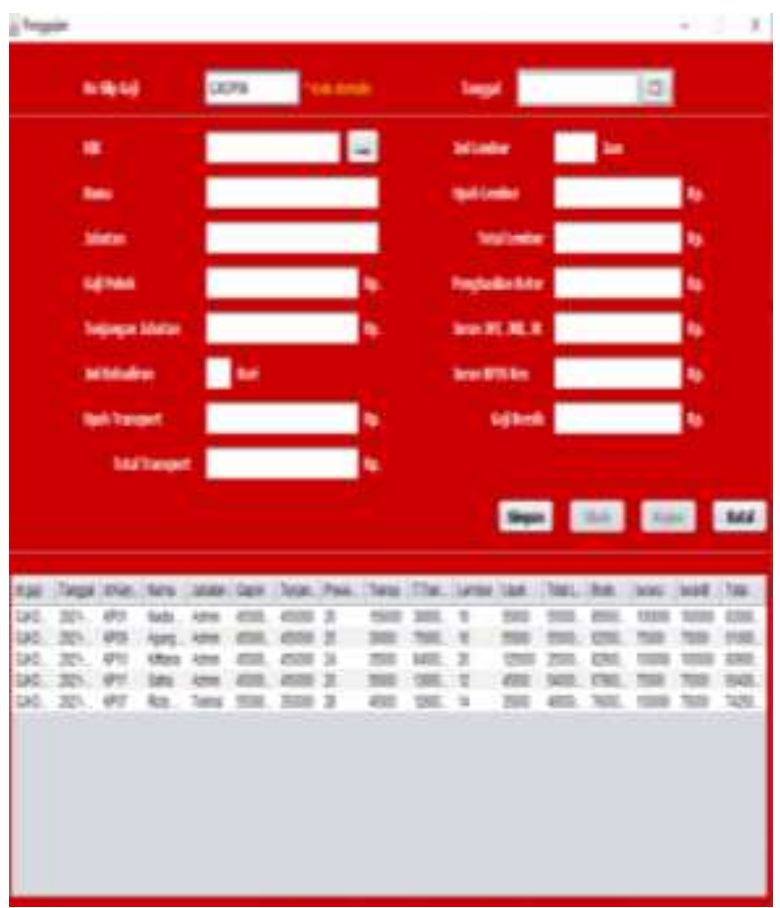

Gambar 6. Form Data Penggajian

Layar di atas menampilkan tampilan form data penggajian. Pada layar form data penggajian untuk meng-input data penggajian yang terdiri dari No Slip Gaji, Tgl, NIP, Nama Pegawai, Jabatan, Gaji Pokok, Tunjangan Jabatan, Jumlah Kehadiran, Upah Transport, Total Transport, Jumlah Lembur, Upah Lembur, Total Lembur, Penghasilan Kotor, Iuran JHT JKK JK, Iuran BPJS Kesehatan dan Gaji Bersih. 


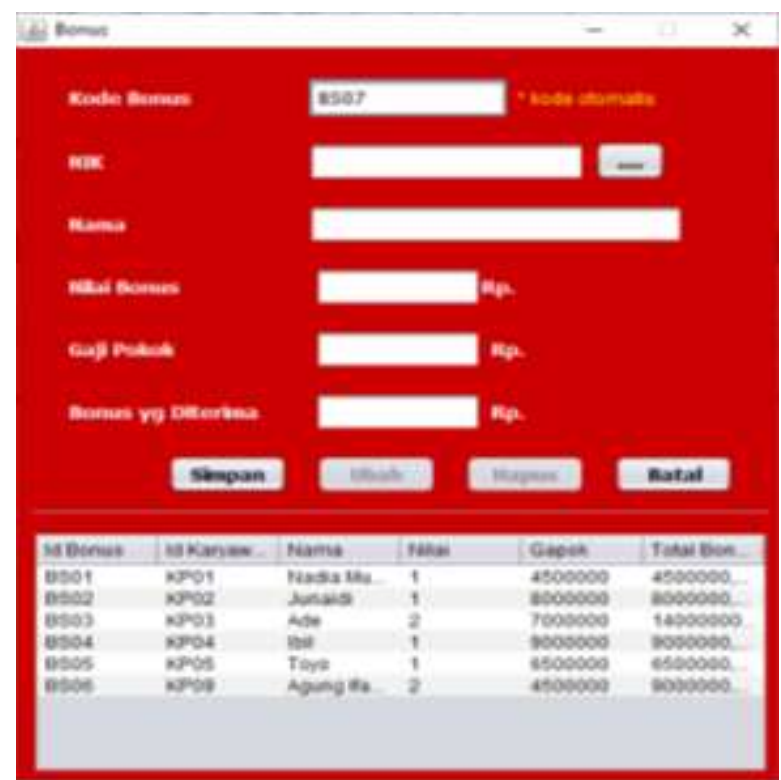

Gambar 7. Data Form Data Bonus Karyawan

Layar di atas menampilkan tampilan form data bonus. Pada layar form data bonus untuk menginput data bonus yang terdiri dari Kode Bonus, NIP, Nama Pegawai, Nilai Bonus, Gaji Pokok, dan Bonus yang Diterima.

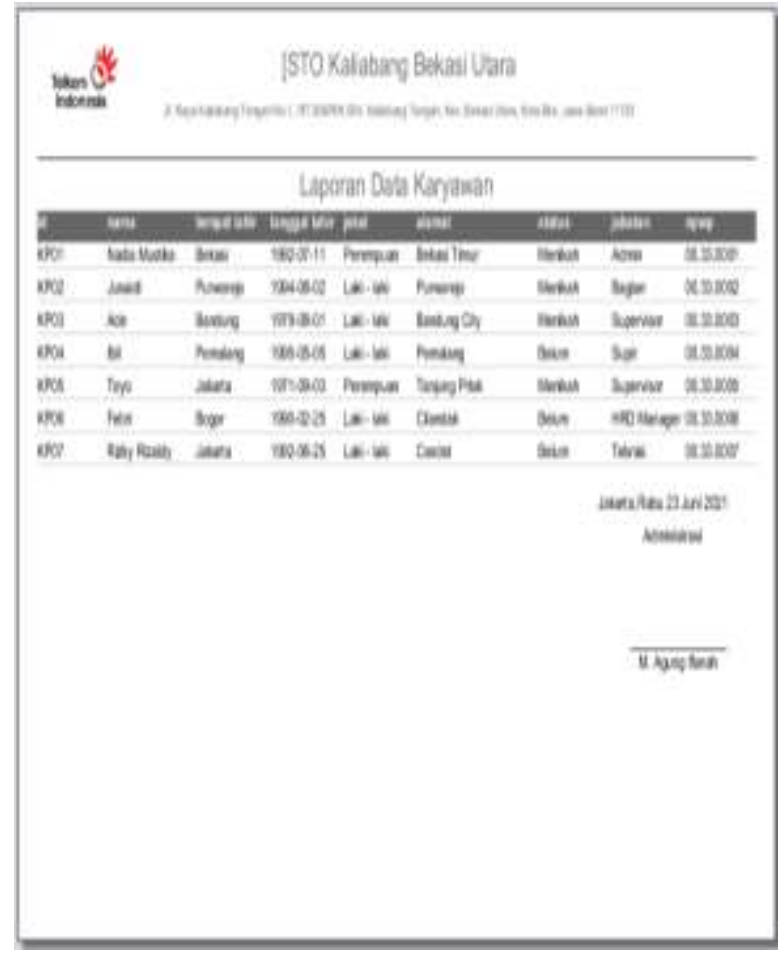

Gambar 8. Laporan Data Pegawai

Layar di atas menampilkan tampilan form laporan data pegawai. Pada layar form data pegawai digunakan untuk mengecek laporan data pegawai terdiri NIP, Nama Pegawai, Tempat Lahir, Tgl Lahir, Jenis Kelamin, Alamat, Status, Kode Jabatan, NPWP.

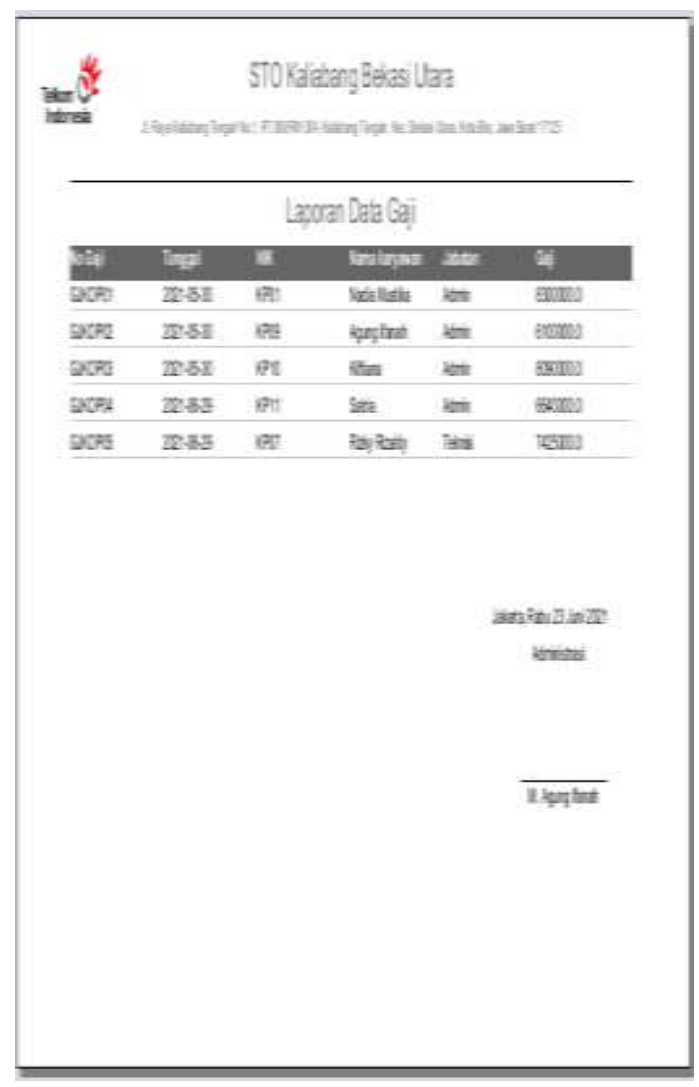

Gambar 9. Laporan Data Penggajian

Layar di atas menampilkan tampilan form laporan data penggajian. Pada layar form data penggajian digunakan untuk mengecek laporan data penggajian terdiri No Gaji, Tgl, NIP, Nama Pegawai, Jabatan dan Gaji. 


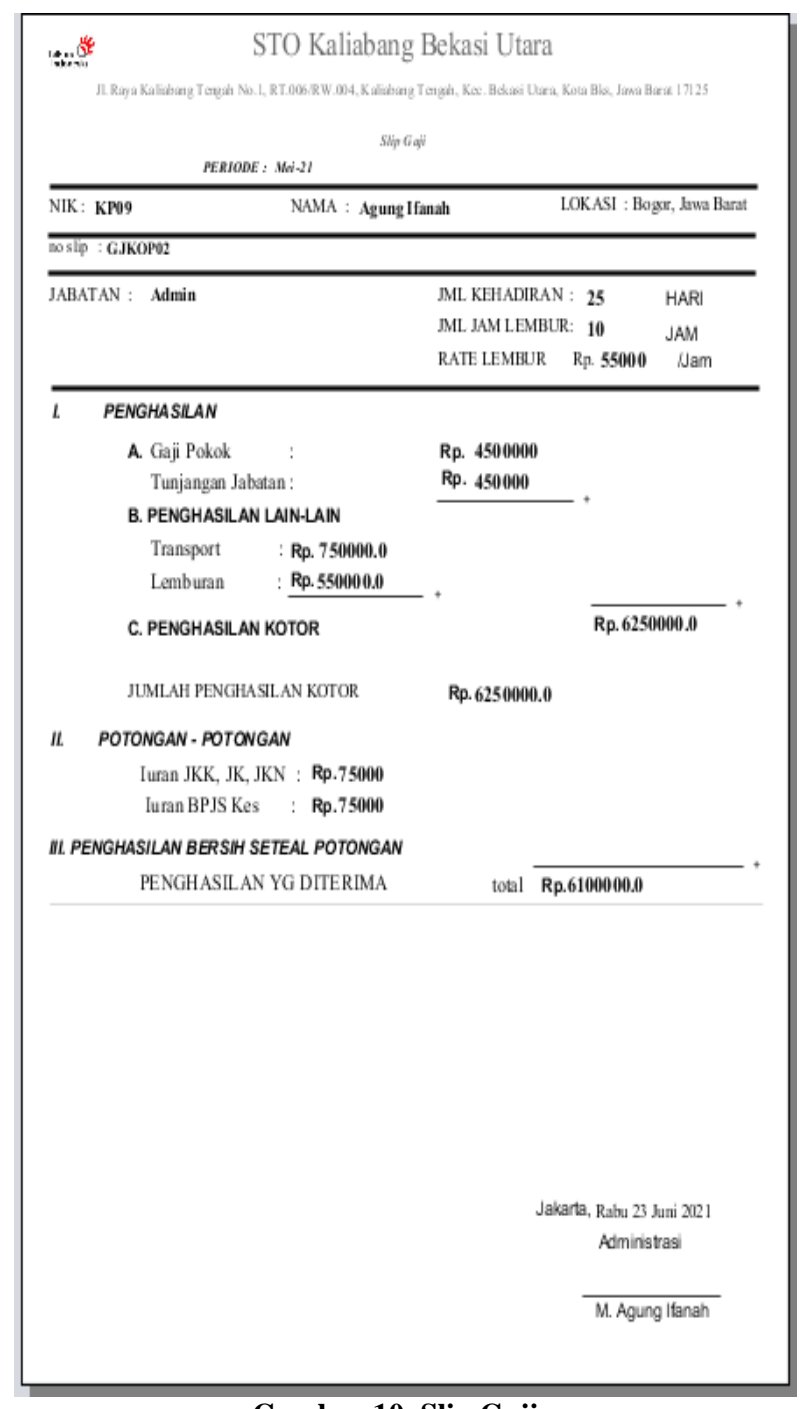

Gambar 10. Slip Gaji

Layar di atas menampilkan tampilan form slip gaji pegawai. Pada layar form slip gaji pegawai terdiri dari No Slip Gaji, Tgl, NIP, Nama Pegawai, Jabatan, Gaji Pokok, Tunjangan Jabatan, Jumlah Kehadiran, Upah Transport, Total Transport, Jumlah Lembur, Upah Lembur, Total Lembur, Penghasilan Kotor, Iuran JHT JKK JK, Iuran BPJS Kesehatan dan Gaji Bersih.

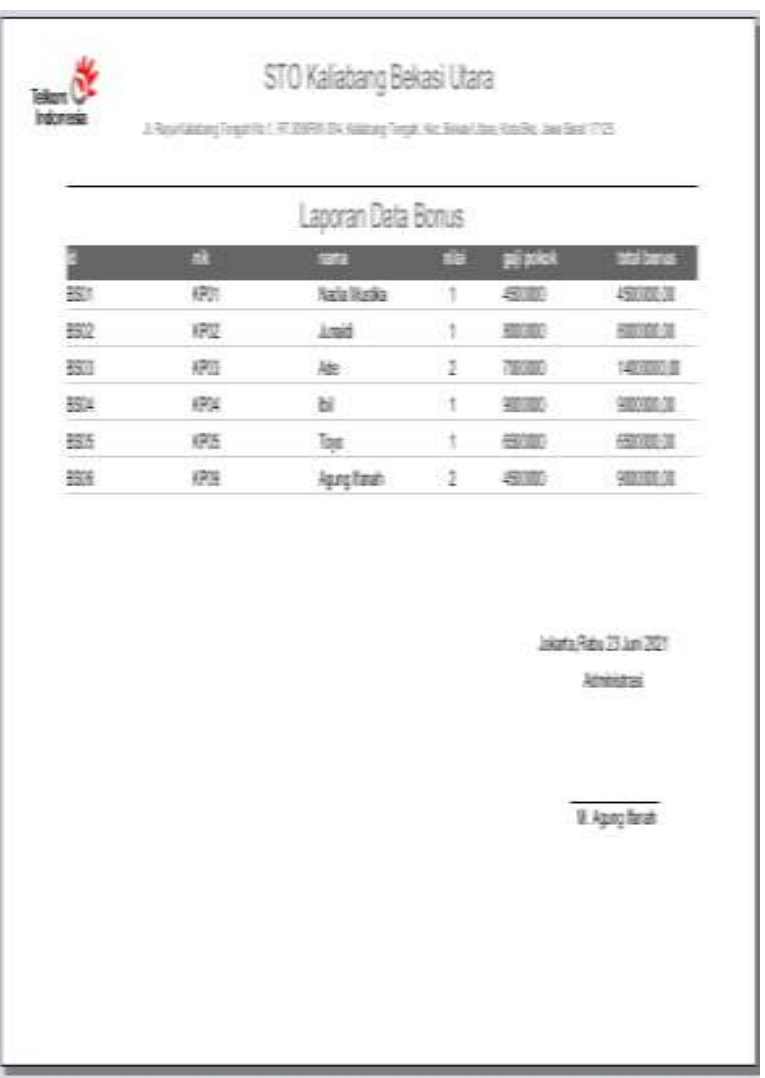

Gambar 11. Laporan Data Bonus

Layar di atas menampilkan tampilan form laporan data bonus. Pada layar form data bonus digunakan untuk mengecek laporan data bonus terdiri ID Bonus, NIP, Nama Pegawai dan Bonus yang diterima.

\section{SIMPULAN DAN SARAN}

Pengolahan data kepegawaian dan penggajian sudah tidak lagi dilakukan secara konvensional tetapi sudah menggunakan sistem yang terkomputerisasi sehingga data yang tersimpan lebih aman. Dirancangnya sistem yang terkomputerisasi ini dalam pembuatan laporan dapat dilakukan dengan cepat dan akurat.

Sarannya adalah sistem baru dilaksanakan, sebaiknya seluruh pihak perusahaan yang terkait dalam sistem harus diberikan penjelasan dengan baik terlebih dahulu mengenai proses kerja sistem yang akan diterapkan sehingga tidak terjadi kekeliruan. Serta perlu dilakukan pelatihan penggunaan sistem tersebut terhadap personil yang terlibat dalam sistem ini agar mereka dapat mengetahui dan memahami cara kerja sistem yang baru. 


\section{DAFTAR PUSTAKA}

J., Suhaimi, M., Sriasih, \& Nurkholis, L. M. (2018). Sistem Informasi Penggajian Pegawai Pada Dinas Tata Kota Pertamanan Dan Kebersihan Lombok Barat. Explore. https://doi.org/10.35200/explore.v8i1.78

Azizah, S. (2017). Perancangan Sistem Informasi Penggajian Karyawan Pada PT. Infiniteam Indonesia. Swabumi.

Dede Firmansyah, H. K. W. A. I. K. (2020). Penerapan Metode Waterfall Dalam Perancangan Sistem Informasi Penggajian Pada Smk Bina Karya Karawang. Jurnal Interkom. https://doi.org/10.35969/interkom.v14i4.56

Fatkhudin, A., \& Alifiani, D. N. (2017). Sistem Informasi Pendaftaran Pasien Pada Klinik Dr. Veri Kajen Kabupaten Pekalongan Berbasis Android. Jurnal Ilmiah Edutic.

Prasojo, M. (2011). Pengantar Sistem Informasi Manajemen bandung: CV. Remadja Karya.

Rahmat Tullah, A. A. (2019). Perancangan Sistem Informasi Data Pasien di Klinik Aulia Medika Pasarkemis. Sisfotek Global.

Satzinger, J. W., Jackson, R. B., Burd, S. D. (n.d.). System Analysis and Design in A Changing World. USA: Cengage Learning.

Sugiyono. (2016). Metode Penelitian Kuantitatif, Kualitatif dan $R \& D$. Bandung: PT Alfabet.

Sutabri, T. (2012). Analisis Sistem Informasi. Yogyakarta: Andi.

Tani, E., Bagre, B., \& Adam, S. (2018). Perancangan Sistem Informasi Kepegawaian PT Sederhana Karya Jaya Berbasis WEB. Seminar Nasional Sistem Informasi Dan Teknologi Informasi 2018 SENSITEK 2018.

Tyoso, J. S. P. (2016). Sistem Informasi Manajemen. Yogyakarta: DeePublish.

Widyasari, F. (2015). Analisis Sistem Akuntansi Penggajian Dan Pengupahan Karyawan Bagian Produksi Sebagai Upaya Mendukung Pengendalian Intern Perusahaan (Studi Kasus Pada CV Sejahtera, Pakisaji â Malang). Jurnal Administrasi Bisnis S1 Universitas Brawijaya. 